\title{
Unsexed Up Androgyny
}

\author{
A.Nasir Yousuf*, A. Kareem Salih \\ Al Wasl University, Dubai
}

*Corresponding Authors: A.Nasir Yousuf, Al Wasl University, Dubai

\begin{abstract}
The purpose of this study is to investigate the way George Bernard Shaw (26 July $1856-2$ November 1950) shaped his female characters. Thus, the analytical descriptive methodology will be adopted. Therefore, in order to explore how Shaw shaped his female characters, a number of concepts such as New Woman, womanliness, gender identity and sexual inversion will be described and analysed. To achieve this end, the research paper focuses on four major questions:
\end{abstract}

1. What are the Victorian concepts related to woman?

2. What are the practices that influence the understanding of woman of the period and gender?

3. How did the theorists and critics of the period evaluate such topics?

4. What are the major features of Shaw's presentation and attitudes towards female characterization?

Keywords: Sexual inversion New Woman Gender identity feminism

\section{INTRODUCTION}

The history of femininity tells that during the Victorian period, sexual discourse invites the issues related to the New Woman (such as womanliness and gender identity): in the courtroom, on the stage, and in the print - both sensational and learned - questions of sexual orientation and definition are raised and discussed by theorists, philosophers, critics, and artists. The conflict underlying the moral code of the Victorian period reflected power grapples that led to the shaping and reforming of sexual identities. This conflict is pointed out by Jeffrey Weeks in Sex, Politics and Society (1981):"The Regulation of Sexuality since 1800, the Victorian age was one of "harsh and repressive sexual Puritanism"; meanwhile "the debate about sexuality exploded" and it "became a major social issue in Victorian social and political practice" (19).Furthermore, the concepts of masculinity and femininity during the Victorian period were seen as issues of great importance to the understanding of the New Woman.

Shaw's relation to these issues and to New Woman's question is noted in his early writings and throughout his career. His involvement in this debate started in The Quintessence of Ibsenism, (1891) and The Philanderer(1893) both of which consider issues of (un)womanly and (un)manly behaviourissues connected seriously with concepts of New Woman, masculinity, femininity and the individual's projection of these characteristics. All these issues together play a central role in Shaw's understanding of woman. Some critics gave this situation much more weight and considered it as the source of Shavian writings.

It is evident that Shavian writings and drama portrayed men and women reflective of the Victorian Age (surrounding circumstances) and its sexual concerns, which has been a continuing topic of debate and fascination. This distinguished group of Shavian characterization mirrors the Victorian's fascination with those whose actions and behaviour seemed at odds with the conventions of gender for their biological sex. Theorists and critics of the period have identified some of these Shavian figures as 'androgynous'; meaning that they display elements of the gender behaviour traditionally applied to their sexual opposites and become not clearly male or female. Nevertheless, this categorization neither accounts for Shaw's fascination with androgyny nor the possible sources for his versions of the phenomenon.

One major criticism of Shaw, as a playwright, is that he presents characters displaying different degrees of trans-sexual traits, from subtle habits through public signs such as cross-dressing and 
strong opposite sex identification. Even though, the continuous presentation of characters identified as androgynous gives way to say that Shaw was a biased androgyny. In his plays and writings, he virtually ignored this phenomenon in men - who were at the time of equal interest of the intellectual Victorian community-focusing almost exclusively on instances in women. Furthermore, Shaw's relation to this practice tells a number of crucial points related to his understanding of womanliness and gender identity in the Victorian era.

This review of the literature provides three distinct influencing works in Shavian depiction of androgyny. The First one of these influencing is the Shakespearean model of the cross-dressed woman who will abandon her masculine attire in the plot resolution. The second is the cross-dressed principal boy figure from the pantomime that often appears in warrior guise, but was always known by audiences to be female "underneath"; and the third one is the androgynous woman discussed in the psychological literature in both homo- and heterosexual variants.

\section{VERSIONS OF VICTORIAN SEXUAL INVERSION}

Different theorists and critics of the period have influenced Shaw's writings on sexual inversion and gender. It is evident that Shaw has a close political and personal connection with Ellis Havelock (In 1897 Henry Havelock Ellis published Sexual Inversion, the first English monograph on homosexuality), John Adding ton Symonds (advocate of male love 'homosexuality'), and Edward Carpenter, psychologists and theorists, who wrote extensively on womanliness and sexuality, particularly the phenomenon of "sexual inversion".

Ellis and Symonds (1975), essentially, stress in their book 'Sexual Inversion', that appearances of inversion do not necessarily imply homosexuality: a 'mannish' woman--- may imitate men on grounds of taste and habit unconnected with sexual perversion, while in the inverted woman the masculine traits are part of an organic instinct, which she by no means always wishes to accentuate. (87-88). In addition, the opening of Carpenter's (1984) study 'The Intermediate Sex' merits quoting at length for it captures the climate of advanced thinking about womanliness and gender, and its final sentence has particular relevance to Shaw's self-conception:

In late years (and since the arrival of the New Woman amongst us) many things in the relation of men and women to each other have altered, or at any rate become clearer. The growing sense of equality in habits and costumes---have brought about a rapprochement between the sexes. If the modern woman is a little more masculine in some ways than her predecessor, the modern man (it is to be hoped), while by no means effeminate, is a little more sensitive in temperament and artistic in feeling. ---It is beginning to be recognized that the sexes do not or should not normally form two groups hopelessly isolated in habit and feeling from each other, but that they rather represent the two poles of one group-which is the human race; so that while certainly the extreme specimens at either pole are vastly divergent, there are great numbers in the middle region who (though differing corporeally as men and women) are by motion and temperament very near to each other.---- Nature it might appear, in mixing the elements which go to compose each individual, does not always keep her two groups ingredients -which represent the two sexes-properly parts--- if a severe distinction of elements always maintained the two sexes would soon drift into far latitudes and absolutely cease to understand each other. As it is, there are some remarkable and (we think) indispensable types of character in whom there is such a union or balance of the feminine and masculine qualities that these people become to a great extent the interpreters of men and women to each other. (189-190)

Ellis similarly, In later writings on the same topic, maintains that the presence of feminine traits in men or masculine traits in women "by no means necessarily indicates the existence of sexual inversion---genius in either sex frequently involves the coexistence of masculine, feminine, and infantile traits" (196). Ellis' notion of "genius" agrees with the Coleridge an proclamation (relating to Samuel Taylor Coleridge or his writings) that a great mind must be androgynous (Watson 1983: 44):

The man who most completely contains the feminine principle and the woman who most completely contains the masculine principle - while at the same time being the gender that he or she is -is the individual within whom the power of life most intensified (40-41).

Watson and Ellis were not alone, as Carpenter's idea that individuals with this balance often become "interpreters of men and women to each other" corresponds to these other two statements. Given Shaw's close relation to Ellis, this could be taken as a theoretical confirmation for Shaw's 
understanding of his success at drawing characters different from himself. The study does not intend to suggest that Shaw was totally a product of these influences, yet no one can deny their important impact on him. Independent of these writings, Shaw had developed a related notion of human similarity, rather than single out the feminine and masculine elements dominant in any individual. As a writer, he pronounced an essential likeness among all people. He expresses an early version of his notion of shared human traits in a letter to his first lover, Alice Lockett:

If you tell a human being, male or female, that she or he has more in common with the most antipathetic other human being on earth of the same age, than he (or she) can possibly have that is unique, you will offend them. Nevertheless, this is so. The reason I know so much about you (and about everybody else) is that at least nine tenth of me is a simple repetition of you. (LettersI:158). In addition, he wrote another letter to Florence Farr, where he voices a sensibility close to the Platonic concept of androgyny, calling her "my other self---- no -- not my other self, but my very self" (Letters I:296).

Some Shaw critics do not see him in the same light in which he presents himself in his letter to Lockett. Smith (1981) contends he "needed the feminine to complete his own masculine assertiveness" (221), suggesting an absence of feminine components in Shaw. In the same way, Ganz (1983) claims that Shaw was unconsciously attracted to such myth as "Pygmalion and Galatea" because they reveal male fears feminine difference (184-185). If this indeed the case, then Shaw may have constructed his notion of human similarity to efface difference - to eliminate the threat of the Other and present women in a fashion in which they can be understood by him, that is, as men.

Not surprisingly, Shaw theorises his understanding of androgyny nature in one of his most striking statements in an essay entitled "Woman-Man in Petticoats" (1927):

People are still full of the old idea that woman is special creation. I am bound to say that of late years she has been working extremely hard to eradicate that impression, and make one understand that a woman is really only a man in petticoats, or if you like, that a man is a woman without petticoats. People sometimes wonder what is the secret of the extraordinary knowledge of women which I shew in my plays. They very often accuse me of having acquired it by living a most abandoned life. But I never acquired it. I have always assumed that a woman is a person exactly like myself and that is how the trick is done. (Platform and Pulpit: 174). $\{1\}$

The essay" Woman-Man in Petticoats" is one of the most interesting feminism writings about womanliness written by Shaw and this quotation merits close analyses as it reveals Shaw's sense of woman and gender. Shaw attributes the source of this sexual distinction to women: "she has been working extremely hard to ---make one understand---." However, this transcription may, or may not, accurately record the sense these unnamed women have of the difference and/or similarities between themselves and men. Shaw's version of the equation neatly corresponds in nature with his own sense of sexual identity. Putting petticoats on a man, you get a woman; and in the same way if one takes them off a woman, you get a man.

- Man+ petticoats= woman

- Woman - petticoats $=$ man

Whatever the case is, the core identity is man. Therefore, one may conclude to the point that Shaw believes a woman is a person like himself with 'petticoats'. The 'petticoat' is a metaphor of the insignificant external differences between man and woman. Obviously, Shaw thinks that all these biological distinctions between female and male are unimportant.

With reference to Shaw's non-dramatic writings and several years before this essay appeared, Shaw had published an article ostensibly on the recent history of female dress and behaviour (but of course equally reflective of Shaw and his views) entitled 'Woman Since 1860 as a Wise Man Sees Her.'. The piece shed light not only on the better known talk quoted above, but also on the complex issue of Shaw's sense of gender identity. Shaw opens his analysis with reflection on his youth, and then proceeds to establish the crucial connection between himself and women:

I was born in the year 1856. Shortly after this, I became conscious of women as immense mounds of flounced dress fabric with waists at the top, and above the waists figures more or less like men, but with ampler bosoms ---. I was dressed like a woman myself, as boys were not then distinguished from 
girls in dress in their early years. I wore frock, under the frock a white petticoat, under the white petticoat a flannel petticoat, under the flannel petticoat a pair of loose white drawers and stays, which were no more than a thick ribbed shirtwaist; under the drawers a chemise, also called a shift or shimmy, and under the chemise my unshiftable skin. And all this a grownup woman wore also, with-the difference that her frock came down to the ground and concealed the fact---- that she had legs and used them just like a man.- -It must be not inferred that because I wore stays as part of my feminine costume, women's stays were necessarily like mine. (10)

In attempt to unsexing himself, this quotation voices Shaw's ideas on one of the aspects of gender identity as it addresses the external appearance of females in the Victorian era compared with males. Although the tone of this narrative maintains a certain intentional naive, its repeated emphasis on dress, age, and gender identity is striking. Dressed like a woman, Shaw realizes at an early age the essential similarities and observable difference between himself and the opposite sex. He perceives association of adult women with children of both sexes in the Victorian era, but also needs to align himself with the male sex he embodies by observing his appearance as similar to the Other's, but not indistinguishable from it.

Thus, his later statement concerning the interchange ability of men and women with or without petticoats seems synthesis of these childhood observations. The same article uncovers Shaw's predilection for certain masculine style in female clothing, which is reflected in his description of characters like Sylvia Craven, in The Philanderer 1893, who wears breeches she can cover with a skirt, as well as the connection he establishes between female cross-dressing and political change within patriarchal society. In other words, Shaw's version of women's clothes history views change as solely male-determined: women only appropriate attire when it became socially acceptable to do so, not as a statement of independence or autonomy on the women's parts. And not surprisingly this also the context in which women appear cross-dressed in his plays, reflecting social change or political revolution which leave room for this urgent need and demand, rather that expressing rebellion against the status circumstances. The article reveals also what Shaw feels is a better alternative for the selfassertion of women:

It was clear to me that what women had to do was not to repudiate their femininity, but to assert its social value not to ape masculinity, but to demonstrate its insufficiency. That was the point of my play Candida (1895), which is made quite plain that the husband's masculine career would go to pieces without the wife's feminine activity. (11)

However, the article introduces vague concepts, which confused Shaw's attitudes towards female behaviour. He does not explain what is the "social value" of femininity is, but this stresses his acknowledgment of the patriarchal thematic of "women's spheres," where the woman brings influence in the house space that is her world, as opposed to the masculine public "career." In Candida(1894) which was published as part of his Plays Pleasant (1898), the reader sees masculine 'shortfall,' but Candida shows this within the private world, the house, so that her "feminine activity," running the household, remains the secret shared by only March banks, Candida, and her husband. The Victorian World Picture knows the women's superior strength and ability, the perfect demonstration of what the women's movement sought to expose. In addition, the writings of female writers and critics about Shaw's woman and gender did not see the play in any way as an exposure of Victorian hypocrisy, but rather as the story of an ideal woman, keeping the secret every woman should keep. Those feminists outnumbered by far those who may have interpreted the play differently.

Furthermore, this statement of Shaw's that points to his own work as a 'solution' to the issue of women's appropriation of male appearance and behaviour implicates him in the debate in a very contradictory way. Shaw closes his article where he began it, with comments on his birth, origins, and beliefs, mixed with a final view and interpretation of the changes he has seen over sixty years:

And now I shall be asked whether I have anything to say about Woman in Thought, in Art, in Shakespeare, in the Musical Classes, and in the glow of her soul. Have I noticed nothing but the position of her stays, the shape of her boots, and the fashion of her dress? I reply, nothing whatever except the changes that have come to us all without distinction of sex. [If there has been a specifically feminine change of soul, I being masculine, cannot know anything about it; for I am too old to have inherited a share of it from my mother; besides, if it could be inherited by a male, it would not be 
specifically feminine.] I do not regard women as animals of another species. I have no difficulty, as a playwright, in making female dramatis personae as easily as male ones; and I conclude that I could do this if I had not a first-hand knowledge of both, being my mother's son as much as my father's. The sexes wear different boots and bonnets, not different souls; that is why I have left the souls out. Ad concentrated on the boots and bonnets. (27).

This concluding paragraph reveals a number of misleading ideas. Here, as elsewhere, Shaw confirms his belief in an essentially identical humanity, that men and women do not have sexually differentiated "souls," only external distinctions. Yet at the same time he asserts this view, he admits the possibility of a feminine soul he cannot know, because he is male, and thus essentially rejects. This example may well be describing a person who is unbalanced and unable to draw fine distinctions. There is the tantalizing possibility that at a younger age, he might have understood this feminine essence through maternal inheritance, but that old age now stops this potential $\{2\}$. This statement continues the theme of Victorian childhood with which he opened the article.

In short, one may conclude to the fact that Shaw's masculine maturation has been a process of loss of the feminine identity he had as a child nevertheless, he maintains he still holds the ability to draw male and female characters equally well. The only way that Shaw can resolve this contradiction is to deny inherent sexual difference. It is clear that Shaw tries to compose his own understanding of gender to claiming that he is capable enough to shape both male and female characters without being bias. However, a close reading of both his plays and fiction reveal something completely different.

\section{EXAMINING THE EFFECT OF SHAKESPEARE'S AND PANTOMIME RESPECTIVELY}

Theorists and critics, generally speaking, consider the period from the late 19th century and up to the beginning of the20th century as a strategic moment in the development of gender discourse. The medical-psychoanalytic theories and writings of Edward Carpenter (29 August 1844 - 28 June, 1929, was an British communist, philosopher, anthologist, and early activist for gay rights and animal rights) and Havelock Ellis(February 2, 1859 - July 8, 1939, was a British physician, psychologist, and social reformer), among others, establish this period as one of heightened sexual consciousness and the literature of the time reflects this preoccupation with gender identity. Definitely, Shaw's plays and writings were among this trend.

However, to position Shaw within the surrounding atmosphere of the Victorian Culture and its consciousness of woman and gender, one needs to step back a little bit and uncover the Renaissance consciousness of gender. This is mainly because of the assumed relation between Shaw and Shakespeare (26 April 1564 - 23 April 1616), given the fact that, the Victorian culture was the logical development of the Renaissance. Shaw's proclaimed links to Shakespeare create a dramatic bridge between the texts from the two eras and enable the study to bring about statements that refer to both Renaissance and Victorian dramas.

Greenblatt (1986) writes a very interesting a book entitled 'Fiction and Friction' Reconstructing Individualism, where he made a number of observations referring to gender in Renaissance drama which is equally valid in the 19th century, particularly with regard to Shaw. Greenblatt says "-- taken as awhole a culture's sexual discourse plays a critical role in shaping individuality. It does so by helping to implant in each person an internalized set of dispositions and orientations that governs individual improvisations. "(30). He locates this connection in the investigation of androgyny and effeminate as they appear in medical/legal records and separately, but coincidentally, in the crossdressing found in the dramatic texts.

Another critic named Felman (1981) gave a very important observation about the position of men and women in the Victorian society saying:

Defined by man, the conventional polarity of masculine and feminine names women as metaphor of man. Sexuality, in other words, functions here as the sign of a rhetorical convention, of which woman is the signifier and man the signified. Man alone has thus the privilege of proper meaning, of literal identity: Femininity as a signifier cannot signify itself; it is but a metaphor, a figurative substitute; it can but refer to man, to the phallus, as its proper meaning, as its signifier. The rhetoricalhierarchization of the very opposition between the sexes is then such that woman's difference is suppressed, being totally subsumed by the reference of the feminine to masculine identity." (19-20). 
Evidently, this situation demonstrates for Felman the male bias of the patriarchal culture, an orientation observed widely by other critics of literary and theatrical androgyny, and one to which Shaw's androgyny conforms. As Shaw uses the attire of characters as an indicator of androgyny, Felamn's ideas on dress were relevant:"If it is clothes, the text seems to suggest, if it is clothes alone, i.e., as cultural sign, an institution, which determine our reading of sexes, which determine masculine and feminine and insure sexual opposition as an orderly, hierarchical polarity; if indeed clothes make the man - or the woman, are not sex roles as such, inherently, but travesties? Are not sex roles but travesties of the ambiguous complexity of real sexuality, of sexual difference?" (28).

It is noticeable the concept of sex roles has been presented and used widely by Shaw. He grapples with this concept in the plays The Man Destiny (1897), Misalliance (1909-1910), and Saint Joan (performed in 1923 and published in 1924). The plays thus reveal traces of the conflict for Shaw between his awareness of the fallacies of strict gender definition and his belief in the social need to maintain sexual difference, essentially for purposes of reproduction and childrearing.

Before discussing and examining Shaw's relation to the concept of sex roles and androgyny in relation to Renaissance consciousness, it is very important for such analysis to show the first appearance of female on stage. The history shows that women had begun to appear on stage for the first time immediately after the Restoration in England. Soon performed cross-dressed in male attire - the 'breeches parts' that became the mainstay of the 18th and 19th century theatre. Felman'squestion belongs directly to the investigation of sexuality and culture as it developed during this period, for society's view of cross-dressing needed to incorporate first the theatrical and literary incarnation of the androgynous female, then later her public identity in male attire. Literary tradition privileges the female character who assumes male attire, like Shakespeare's Rosalind in his five actcomedy As You Like It (written and performed about 1598-1600).

However, the female cross-dresser became an object of both fascination and controversy, as she was not only the sex symbol but also a threat to patriarchal control through her usurpation of male attire, behaviour, and action. It is noticed that this conflict is resolved in various ways:

1. by emphasizing the feminine sexual seduction in the male disguise,

2. by interpreting the female aspiration to male identity as are cognition of male superiority,

3. by incorporating the cross-dressing in a comic context that would diffuse the anxiety surrounding the issue of sexual difference.

The sexual component of dramatic cross-dressing had distinguished theatrical transvestism from that of female modernists who made their sporting of female attire apolitical act more overtly threatening to the dominant male culture. Taking the example of the Godfather of the Renaissance drama, Shakespeare, and his treatment of this case, some relevant point could be made. The Shakespearean plot device of the male-disguised female stands as a touchstone for subsequent dramatic instances of male impersonation. Audience respond positively to female assertiveness when masked by male attire, but the temporary nature of this sartorial transgression is integral to the resolution of the social disruption, which shapes Shakespearean comedy (Park 1980: 108). In other words, the resolution of order in Shakespearean world must always include a return to conventional gender roles.

Auerbach (1987) interprets this phenomenon for 19th century audience: Perhaps because they flirted with the forbidden, Portia, Rosalind, and Viola, who act men for a while but happily give up their masquerade at the end of the play, were really loved by Victorian audience who basked in transvestism displaced into disguise. None of these women is transformed into male--- Each remains a woman underneath, claiming male prerogatives only in order to educate the childish hero she loves. Such plays challenged Victorians audiences just enough to ally their more far-reaching fears. What makes this argument interesting is the different ways critics see gender identity.

In addition to the abovementionedexamples, in his analysis, Kimbrough (1982) sees female crossdressingin Shakespeare as an attempt to expose these conventions of gender and allow a character to grow "into a fuller human self" (23). "Just as an actor's role is a disguise, so also is gender a disguise, and all disguises must be removed for people to be themselves" (27). 
Turning to the assumed relation between Renaissance and Victorian dramas in treating the cases of gender identity and sexroles in society, brings suggestions of Greenbaltt (1986) into focus. Greenbaltt accounts for the dominance of female androgyny in the English theatre as integrally related to Renaissance conceptions of the emergency of male identity. The female characters' assumption and subsequent giving up of male costume provides a mirror image for the process by which a maturing male distinguishes himself from the female (51).Bernard Shaw, who saw himself as an inheritor of Shakespearean tradition, may well have subconsciously adopted this motif for reasons similar to those suggested by Greenbaltt.

Shaw employs this trope of the cross-dressed female frequently in his One-Act, as well as full-length comedies, and the Shakespearean model may have affected, or even suggested Shaw's consciousness of cross dressing. It is difficult to say whether he was or was not aware of this. It is observed that when women took over the roles of male impersonators after the Restoration, they not only portrayed the cross-dressed Shakespearean heroines. Instead, they also took on certain younger male roles in Restoration and 18th century and branched out into the popular theatre, namely the pantomime (where actors tell a story without words, by means of bodily movements, costume, gestures, and facial expressions).Thus, the pantomime theatre had much to do in forming Victorian audience's attitudes towards gender identity and sex roles in society.

Between 1815 and 1819, the first breeches roles - those filled by actresses in male disguise - entered the English pantomime theatre. These roles evolved over the next few decades into the Victorian pantomime fixture known as the "principal boy": the young male hero portrayed by an actress(usually of noteworthy sexual appeal) cross-dressed to accentuate feminine allure while suggesting traditional boyish appearance(Senelick 1982: 32).

Surprisingly, Shaw who is usually so vocal about actresses, is peculiarly quiet about the distinctive presence of women in this form of entertainment. It is true that one rare comment however shows his clear appreciation of the connection between the Shakespearean tradition and the performances of his own day. In a letter to Max Beerbohm, he accuses the critic of believing "Rosalind the pantomime' leading boy' is a real woman" (Letters II: 373). Also, Meisel(1963), in his study of the dramatic influences on Shaw includes a discussion of pantomime, burlesque (a type of writing or acting that tries to make something serious seem stupid), and related theatricals and notes that Shaw claimed he spent little time during his youth at the Queen's Theatre in Dublin, the house for popular entertainment. Although, Meisel remarks that Shaw "remembered [the theatre] not quite accurately" (15), he does not overtly question Shaw's dismissal of these theatrical forms, despite his observation that

during Shaw's young adulthood in Dublin this same theatre received a visit by Mrs. John Wood and her company from London, which specialized in an alternating repertory of legitimate drama and burlesque (15-16). Instead, Meisel directs the readers' attention to his later description of burlesque and pantomime and its influences on Shaw's Androcles and the Lion (1912). In his analysis, however, Meisel does refer specially to the work of Planche, the creator of numerous spectacles based on fairy tales and/ or fables (384-388).

A popular academic/ aesthetic critics, named Fletcher (1987), in her study of Planchĕ and Madame Vestris, notes: "The form which extravaganza assumed was largely the result of collaboration between James Robinson Planchě and Madame Vestris" (10). Vestris (1797-1856), one of the foremost male impersonators of the 19th century, was also an actressmanagerwhose career included operating London's Olympic theatre. Her attractive figure, singing voice, and dancing abilities suited her ideally to principle boy roles; Fletcher counts "twentytwomajor transvestite roles in the Planche extravaganzas" and" numerous minor roles as well" of which "Vestris created the greatest number" (24). Meisel makes no mention of Vestris or cross-dressing in Shaw, although he discusses at length the way that male and female character types from the popular theatre- but not the sex that performed them--worked their way into Shaw's plays. He also quotes one pantomime review, which mentions the actresses' name in the principle boy roles (330), but offers no commentary on this element of those productions, most probably because Androcles and the Lion (1912)has no cross-

Not only that but Similarly Morgan (1972) dismisses this influence entirely:" Significantly, Shaw avoided the music hall as a model" (48). It would be more accurate to say that Shaw spoke of the music hall as a negative model, one that could be perceived as influential on his plays if they were 
acted incorrectly. It would appear Shaw wanted to eliminate any potential association of his work with this form popular entertainment, but this negative identification points to the actual relation of Shaw's work with the female transvestism of the popular stage. In a letter to Vesta Tilley the actress portraying Lina, the androgynous character in Misalliance (written in 1909-1910), he explains, "I am writing to Tarleton to say that if he would work less conscientiously for a Vesta Tilley success, with you as the representative of "the girls—the Gy-erls," he would find the scene easier for himself as well as for you." (Letters IV: 181).

Vesta Tilley (1864-1952) transported the techniques of male impersonation to the music hall stages from their origins in breeches parts and in the pantomime, where she performed principal boy roles early in her career. The foremost impersonator male of her era, Tilley sportive graceful costumes that reputedly set the tone for off-stage fashions, confuses the line, which originally separated actresses from female cross-dressing modernists, and even from the men who adored Tilley's trend-setting attire. Morgan's insightful reading of Shaw incorporates much analysis of the importance of the commedia dell'arte (comedy of professional actors) for his work. Nevertheless, the source of Shaw's knowledge of the commedia goes unexamined. The filtration of these character types through Shakespeare is well-documented, but the most direct lineage emerges in the popular theatre.

Booth(1976) notes: Early nineteen-century pantomime directly descended not only from the traditions of commedia dell'arte as they had evolved for centuries, but also from the distinctively English pantomime of the eighteenth century, an amalgam of serious scene from classical and modern legend or fable with unrelated harlequinade episodes. $\{2\}$ In a footnote, Booth calls his readers' attention to two Shaw reviews of pantomimes, both contained in the third volume of Our Theatre in the Nineties, on 1st January and 9th of April1898. Interestingly, Shaw makes no mention on these pieces of the figure of the principal boy, although he does praise the performance of several actresses whose roles are unspecified.

In Shaw's preface to William Archer's Theatrical 'World' of 1894, he mentions the above-named Mrs. John Wood as a theatrical manageress (xvi), but makes no reference to her other identity as "Queen of the Burlesque" (Meisel 16). In that same volume Archer reviews two pantomimes, Cinderella and Jack and the Beanstalk, and he praises the actresses playing specifically identified boy roles in each $(5,8)$.

Shaw's participation in relation to the history of pantomime, as a theatrical phenomenon, is very crucial to the understanding of his consciousness of woman. Mander andMitchenson's (1973) history of pantomime features a lengthy extract from a review By Shaw in The Era, 30 December 1937.In the article, Shaw reveals his view of the form: "I have seen dozens of them; and not one had amused me since I was a very small child and thought it all real" (44). He directs his comments to an analysis of the deterioration of technique in actors portraying the harlequin role (a form of theatrical entertainment derived from commedia dell' arte where a humorous character wears brightly coloured clothes with a diamond pattern), and again makes no mention of actresses or the tradition of the principal boy.

It is very important to keep bringing this situation of being silent about female in male disguise in pantomime theatre into focus and to analysis Shaw's attitudes towards this theatrical genre because it has much to do with his identification of gender and woman. The prominence of the principal boy role in the pantomime (for example the Prince in Cinderella and Jack and the Beanstalk), coupled with the stature of the actresses in the seroles, could not have gone unnoticed by Shaw, who clearly had ample opportunity to observe their performances. Shaw's silence on these characters may account for Meisel's not mentioning them, but it is interesting that he does not connect the incidence of crossdressing in the plays with this tradition. In fact, he makes no mention of this dramatic Phenomenon.

Shaw is equally silent on Ellen Terry's association with breeches parts, despite their long, close connection. Terry's career started with these roles (Auerbach 50), although Shaw first encountered her work after she had begun predominantly to act parts for mature women. He makes no mention of these roles in his semi-biographical preface to their correspondence (viixxviii),nor does the male disguise of Imogen have any place in Shaw's extensive communication with Terry about her performance in the Irving production of Shakespeare's romance Cymbeline (also known as The Tragedie of Cymbeline or Cymbeline, King of Britain) .The Shakespearean troop of the woman-inmale disguises breaking away with this role to return to more conventional femininity, which may 
have its most unexpected version in the violence of the transformation in Act V of Cymbeline, $\{3\}$ has a direct parallel in the Victorian pantomime - the Transformation Scene, in which the principal boy role is transformed to the commedia harlequin. A part played by a male actor during the final harlequinade, so that the properly sexed up romantic conclusion can be resulted from using such techniques.

To explain what is meant exactly by transformation scene, and its importance to the understanding of gender identity, one needs to refer to the pantomime practice. In the pantomimes of Shaw's time, the actress in the principal boy converted in68boyish fashion throughout the main action of the performance, usually based on fairy tale or legend. The productions ended, however, with an extravaganza of theatricality, a harlequinade unrelated to the main action, but which usually united the hero and heroine in their commedia incarnation. The transformation from pantomime action to the harlequinade, called the Transformation Scene, always included the replacement of the principal boy actress by male actor, so that a man as Harlequin and a woman like Columbine would resolve any romantic action. Although two women had 'set the stage' in the pantomime, essentially representing what one might now think of as lesbian couple masquerading as a heterosexual unit, neither audiences nor critics viewed them this way then because of the theatrical conventions that had basically reversed the tradition of male actor in all roles. However, this situation maintained the illusion of heterosexuality that defined the form of "suspension of disbelief" for the stage. It is noticed that, this troop of female replacement structurally resembles the patterns for the New Woman fiction.

In the more fantastical pantomime incarnations, the woman is similarly returned to her "proper role" at the play's conclusion: actresses appear only in the costume and character proper to theirsex. The external transgressions of women's appropriation of male dress and behaviour(surprisingly, the Sudanese theatre adopted a different practice in the end of the 20th century as the most popular Sudanese actor Al-Fade Saeed played number of roles of male-in-woman disguise 'Bit Qudaim') in Shakespeareand pantomimes resolve in the return to traditional female costume and behaviour (or in the injunction to do immediately after the plot resolution). The significance of the outcome here - the restitution of male authority and the correct social order-is thus the same as before, although the rationale for assuming the disguise initially is not as threatening to the patriarchy here as was that of the New Woman, who made conscious efforts to destroy male authority and privilege. This strategic difference, that the women assume their disguise in the service of love or the interests of men, lies at the heart of their acceptability in a society as concerned with gender identity as the Victorian.

\section{CONClusion}

George Bernard Shaw is famous for being an intellectual progressive playwright as the scholars and critics tried to position among the elite of his time. Yet, the close analyses of his both dramatic and non-dramatic writings in relation to the feminism criticism reveals that he frequently views Victorian female as a second class citizen, or as most cases remains silent. Evidently, this attitude towards woman works in harmony with the Victorian doctrines and conflicted with Shaw's beliefs as socialist to offer more equal or independent options for women through the word he creates.

In addition, the research paper reveals that Shaw as a playwright represents female characters displaying different degrees of trans-sexual traits, from subtle habits to public signs such as crossdressing and strong opposite sex identification. This practice gives way to the fact that Shaw is a biased androgyny as he ignored the phenomenon in men focusing almost exclusively in woman.

\section{BIBLIOGRAPHY}

[1] Auerbach, Nina. Ellen Terry: Player in Her Time. New York: Norton, 1987.

[2] Booth, Michael. Introduction. Pantomimes, Extravaganzas and .Burlesques. Ed. Booth. Oxford: Clarendon, 1976.

[3] Carpenter, Edward. The Intermediate Sex. 1906. Edward Carpenter, -Selected Writings: Volume 1: Sex. Ed. Noël Greig. London: Gay Men's Press, 1984.

[4] Collected Letters. Ed. Dan H. Laurence. 4vos. London: Max .Reinhardt, 1988

[5] Ellis, Havelock and John Addington Symonds. Sexual Inversion (1897). New York: Arno, 1975.

[6] Felman, Shoshana. " Rereading Femininity." Yale French Studies 62, -1981. Eds. Thomas C. Heller, MontonSosna, and. Davis E. Wellbery. Stanford: Stanford UP, 1986.

[7] Ganz, Arthur. George Bernard Shaw. New York: Grove, 1983. 
[8] Greenblatt, Stephen. " Fiction and Friction." Reconstructing -Individualism. Eds. Thomas C.

[9] Heller, MontonSosna, and Davis E. Wellbery. Stanford: Stanford UP, 1986

[10] Kimbrough, Robert. Androgyny Seen Through Shakespeare's Disguise" -.Shakespeare Quarterly 33, 1982.

[11] Mander, Raymond and Joe Mitchenson. Pantomime: A story in -.Pictures. New York: Taplinger, 1973

[12] Meisel, Martin. Shaw and the Nineteenth Century Theatre. 1963. New -York: Limelight Editions, 1984

[13] Morgan, Margery M. The Shavian Playground: An Exploration of the Art of George Bernard Shaw. London: Methuen, 1972

[14] Park, Clara Claiborne. " As We Like It : How a Girl Can Be Smart and- Still Popular." The Woman's Part: Feminist Criticism of Shakespeare. Eds. Carolyn Ruth Swift Lenz, Gayle Green, and Carol Thomas Neely. Urbana: U of Illinois P, 1980

[15] Platform and Pulpit. Ed. Dan H.L aurence. New York: Hill and .Wang, 1961.

[16] Shaw, George Bernard. Agitations: Letters to the Press 1875-1950. Eds. Dan H. Laurence and James Rambeau. New York: FrederickUngar, 1985.

[17] Senelick, Laurence. " The Evolution of the Male Impersonator on the-Nineteenth- Century Popular Stage" Essays in Theatre 1.1982

[18] Smith, Warren Sylvester." The Adventure of Shaw, the Nun, and the -Black Girl." Shaw 1 1981. Ed. Dan H. Lauren London: Max. Reinhardt, 1988.

[19] Watson Jean. “Coleriage’s Androgynous Ideal." Prose Studies 6, 1983.

[20] Weeks, Jeffrey. Sex, Politics and Society: The Regulation of Sexuality since 1800. London: Longman.1981.

[21] Woman Since 1860 As a Wise Man Sees Her." Shaw Platform and" .Pulpit. Ed. Dan H. Laurence. New York: Hill and Wang, 1961.

\section{NOTES}

\{1\} Shaw might have gotten this idea from John Stuart Mill's(1970), The Subjection of Women, a tract influential on his concept of sexual equality and referred to specifically in his play You Never Can Tell. The Edinburgh Review article (Ed. Dan H. Lauren London: Max Reinhardt, 1988) on Mill's Book states "we altogether reject [Mill's] hypothesis that woman is man in petticoats" (306).

\{2\} This concept has Coleridge an echoes not dissimilar to the sense of Coleridge an androgyny Shaw have adopted. Like the infant 'trailing clouds of glory,' the young Shaw loses the balance sensitivity to both sexes as he grows.

\{3\} Imogen's husband Posthumous does not recognized his wifein her disguise as the boy Fidele and brutally strikes her to the ground immediately before her true identity is revealed to him by his servant Pisanio)

Citation: A.Nasir Yousuf, A. Kareem Salih. Unsexed Up Androgyny "International Journal on Studies in English Language and Literature (IJSELL), vol 8, no. 5, 2020, pp. 57-66. doi: http://dx.doi.org/10.20431/23473134.0805008 .

Copyright: () 2020 Authors. This is an open-access article distributed under the terms of the Creative Commons Attribution License, which permits unrestricted use, distribution, and reproduction in any medium, provided the original author and source are credited. 